\title{
AN ENUMERATION OF COLLECTIONS OF BAUHINIA SUBGEN. PHANERA (LEGUMINOSAE: CAESALPINIOIDEAE) FROM BANGLADESH IN CENTRAL NATIONAL HERBARIUM (CAL), INDIA
}

\author{
S. BANDYOPADHYAY ${ }^{1}$ \\ Botanical Survey of India, P.O. Botanic Garden, Howrah 711 103, \\ West Bengal, India
}

Key words: Bauhinia subgen. Phanera, Collections, CAL, Bangladesh

The fascicles of the Flora of Bangladesh with detailed taxonomic accounts of the angiospermic families are being published in series of numbers and the latest of them is by Khan and Khanam (2003).

In this paper the collections of Bauhinia subgen. Phanera from Bangladesh in Central National Herbarium (CAL), India have been enumerated with a view to draw the attention of the researchers engaged in the preparation of detailed taxonomic account of the subgenus in Bangladesh.

The enumeration is as follows:

1. Bauhinia nervosa (Wall. ex Benth.) Baker in Hook. f., Fl. Brit. India 2: 283. 1878. Phanera nervosa Wall. ex Benth. in Miq., Pl. Jungh. 262. 1852.

Representative specimen: Mt. Sillhet, Wall. Cat. no. 5777, herb. acc. no. 137449.

Note: Wall. Cat. no. 5777 is the type of P. nervosa. The Wallichian specimens having no. 5777 are also in K, photo. - CAL! and K-W, photo. - CAL!

2. Bauhinia ornata Kurz var. kerrii (Gagnep.) K. Larsen \& S. S. Larsen in Aubreville \& Leroy (eds.), Fl. Cambodge, Laos \& Vietnam 18: 208. 1980. B. kerrii Gagnep. in Lecomte, Not. Syst. 2: 173. 1912. Phanera rufa Benth. in Miq., Pl. Jungh. 263. 1852. Bauhinia rufa (Benth.) Baker in Hook.f., Fl. Brit. India 2: 280. 1878, 'rufa Grah.', non Steud. (1840).

Representative specimen: M. Sylhet, Wall. Cat. no. 5798, herb. acc. no. 137237.

Note: Wall. Cat. no. 5798 is the type of P. rufa. The Wallichian specimens having no. 5798 are also in K, photo. - CAL! and K-W, microf. - CAL!

3. Bauhinia scandens L., Sp. Pl. 374. 1753. B. anguina Roxb., Pl. Coromandel 3: 82, t. 285. 1820.

Representative specimens: Chittagong, J. D. Hooker \& T. Thomson s. n., herb. acc. no. 137692; Chittagong, Bariadhala,10.10.1905, D. Hooper 25919; Silhet, Wall. Cat. no. 5773a, herb. acc. no. 137701; Silhet, Wall. Cat. no. 5773A, herb. acc. no. 137702.

\footnotetext{
${ }^{1}$ E-mail: subirbandyopadhyay@yahoo.com
} 
Note: The collection of D. Hooper 25919 is with immature inflorescence and identified as Bauhinia integrifolia Roxb. on the herbarium label. In an additional strip of paper there is a note saying "Not recorded in Fl. Br. Ind for Chittagong-Burma area nor in the Calc Herbarium (Fl. Br. Ind p 279) Nos. 14-16. It is not B. retusa Ham which is ecirrhose, \& is confined to the Western Himalayas. It is not bidenta(ta) which has leaves longer than broad”. The given identity is, however, not correct. Ms. S.S. Larsen (pers. comm. 1997), Aarhus University, Denmark has kindly identified it for me as B. scandens.

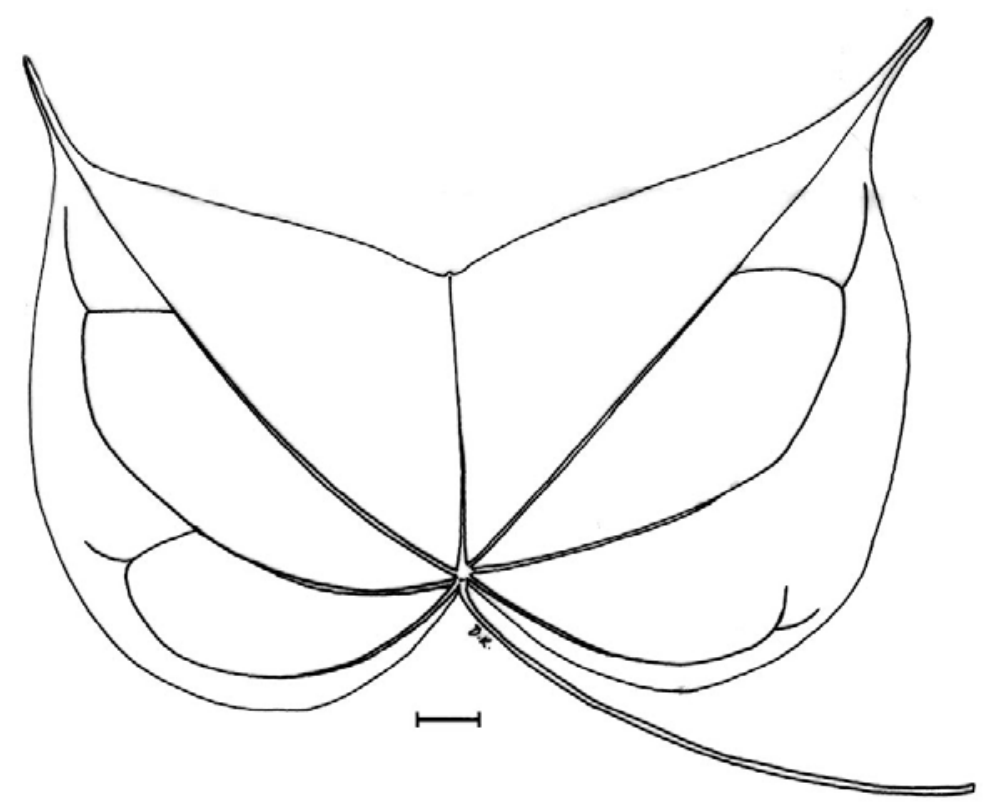

Fig. 1. Bauhinia sp.: A leaf from J. L. Lister s.n. with widely diverging lobes at apex. [Scale $=1 \mathrm{~cm}$ ]

The sheet having Wall. Cat. no. 5773a has a flowering collection of B. scandens and three leaves of B. roxburghiana Voigt. The latter species, however, occurs in India, Nepal and Pakistan, but not in Bangladesh.

4. Bauhinia wallichii J. F. Macbr. in Contrib. Gray Herb. Harvard University (n.s.) 3(59): 23. 1919. Phanera macrostachya Benth. in Miq., Pl. Jungh. 262. 1852. Bauhinia macrostachya (Benth.) Benth. in Benth. \& Hook.f., Gen. Pl. 1: 576. 1865, non Benth. (1840).

Representative specimens: Wall. Cat. no. 5774a, herb. acc. no. 137352; Silhet, Wall. Cat. no. 5774A, herb. acc. no. 137351. 
Note: Wall. Cat. no. 5774 is the type of P. macrostachya. The Wallichian specimens having no. 5774 (see Bandyopadhyay, 2001: 10) are also in K, photo. - CAL! and K-W, photo. - CAL!

Another specimen S.K. Mukherjee 79 collected from Chittagong Hill Tracts in Feb. 1940 and labeled as Bauhinia macrostachya Wall. exists in CAL, but the identity of this sterile specimen could not be determined.

In addition to the afore-mentioned collections, two other collections (East Pakistan, Chittagong Hill Tracts, Mynimukh forest, 25.12.1956, M. S. Khan 244; Chittagong Hill Tracts, Myani mukh, Feb. 1876, J. L. Lister s.n., herb. acc. no. 137356) identified as Bauhinia divergens Baker / Phanera divergens (Baker) Thoth. are in CAL. This species, however, do not actually exist in nature. Larsen and Larsen (1979) has pointed out that the type (Birma, Griffith 1895 - K, photo. - CAL!) of B. divergens Baker represents a mixed collection: "flowers and young pod from Bauhinia variegata L., while a sterile branch with leaves probably belongs to $B$. scandens L.”. Many such collections were examined with leaves having widely diverging lobes at apex, typically as in $J$. L. Lister s.n. (Fig.1), from Eastern and North-Eastern India and some adjacent countries in CAL having the names $B$. divergens / P. divergens but all of them were sterile. Mr. M. K. Pathak who is working on the flora of Dibang Valley in Arunachal Pradesh, India informed (pers. comm. 2006) that during his field studies he had seen such type of leaves in some plants in two localities in Arunachal Pradesh, namely, in Kornu-Difunala and near the helipad in Roing. The plants were 3-4 m in length and were creeping on the forest floor or climbing up on the trees. Their stems were terete, about $5 \mathrm{~mm}$ in diameter but the plants were, however, without flowers or fruits. More field observations are necessary to see that to which species the leaves actually belong to.

\section{Acknowledgements}

I am thankful to the Director, Botanical Survey of India for his help and encouragement and to the anonymous reviewer for his helpful comments.

\section{References}

Bandyopadhyay, S. 2001. Miscellaneous notes on Bauhinia L. (Leguminosae: Caesalpinioideae) - II. J. Econ. Taxon. Bot. 25(1): 10-12.

Khan, M.S. and Khanam, M. 2003. Cuscutaceae. In: Rahman, M.M. and Khanam, M. (eds.), Flora of Bangladesh 55: 1-11, Bangladesh National Herbarium, Dhaka, Bangladesh.

Larsen, K. and Larsen, S.S. 1979. Nomenclatural notes on some old world Bauhinia. Taxon 28(5/6): 591592. 